\title{
Heavy metal pollution assessment of granite quarrying operations at Ikole-Ekiti, Nigeria
}

\author{
Olufemi Julius Ayodele, Olubunmi Samuel Shittu, Temitope Balogun
}

Department of Crop, Soil and Environmental Sciences, Ekiti State University, Ado-Ekiti, Nigeria

\section{Email address:}

olubunmishittu@yahoo.com (O. S. Shittu)

\section{To cite this article:}

Olufemi Julius Ayodele, Olubunmi Samuel Shittu, Temitope Balogun. Heavy Metal Pollution Assessment of Granite Quarrying Operations at Ikole-Ekiti, Nigeria. International Journal of Environmental Monitoring and Analysis. Vol. 2, No. 6, 2014, pp. 333-339.

doi: 10.11648/j.ijema.20140206.16

\begin{abstract}
The impact of previous operations on the environment was assessed by determining heavy metal contents of soil (topsoil, 0-15 cm and subsoil,15-30 cm) and plant samples taken at 0, 10, 15, 30, 60, 120 and $200 \mathrm{~m}$ from an abandoned granite quarry and compared to samples from a control (baseline) location. Fe was the most abundant element in the topsoil (0$15 \mathrm{~cm}$ ) and subsoil $(15-30 \mathrm{~cm})$, Cd was below detectable level while other elements were present in the order: $\mathrm{Mn}>\mathrm{Cr}>\mathrm{Pb}>\mathrm{Ni}>\mathrm{Cu}>\mathrm{Co}$. $\mathrm{Fe}, \mathrm{Pb}, \mathrm{Cu}, \mathrm{Cr}$ and $\mathrm{Ni}$ were highest at $0 \mathrm{~m}$ and decreased with distance from the quarry site. The metals showed deficiency to moderate enrichment and low to moderate contamination at some distances but more in the topsoil than in the subsoil such that the Pollution Load Index (PLI) was $<1.0$ at all points in the topsoil. Fe and Mn were most abundant in all the plants and Aspilia africana contained the highest $\mathrm{Pb}$ and $\mathrm{Co}$ while $\mathrm{Ni}$ was highest in Synedrella nodiflora and Chromolaena odorata. The Transfer Factor, Shoot: Root Quotient and Extraction Coefficient exceeded 1.00 for most of the heavy metals especially at 0 and $10 \mathrm{~m}$. The potential of Chromolaena odorata for Fe accumulation was indicated just as Sida scabrida would be an excluder of $\mathrm{Cu}$.
\end{abstract}

Keywords: Granite Quarry, Heavy Metal Enrichment, Pollution Load Index, Transfer Factor, Bioaccumulation

\section{Introduction}

Sustained investment in the development of the solid mineral sector to diversify the revenue base from crude oil export is a major thrust in the economic transformation agenda of the Nigerian government and through which the country will be one of the top 20 economies by year 2020 (Mallo, 2012). The prospects lie in the diverse solid minerals of 33 different types occurring in large quantities in 450 locations within the geological formations: pre-Cambrian igneous and metamorphic rocks of the basement complex; and sedimentary rocks but which are in poor stages of exploration and even poorer stages of exploitation for export (Odeyemi, 2001).

Ekiti State is located in the western portion of the basement complex in Nigeria. with characteristic upland physiography (average $>250 \mathrm{~m}$ elevation) and undulating topography of expansive ancient plains broken by intermittent steep-sided outcrops, dome-shaped inselbergs and singular or ridge of residual hills whose major rocks are granite (fine, medium and coarse-grained biotite-granite and biotite-hornblende granite) and charnockite, gneiss, and quartzite (Oyinloye and Obasi, 2006; Shitta, 2010). Huge economic benefits can be derived from the sustained exploitation of these rocks and rock minerals through modern large-scale quarrying operations.

A quarry is an open-pit mine from which rocks or rock minerals are extracted through various processes that may comprise removal of the topsoil (overburden), drilling, blasting with explosives and use of machinery to crush and grade rock materials and for transportation. Quarrying, as every mining operation, is a destructive development activity whose socio-economic benefits may be unable to compensate for the overall detrimental effects on natural ecosystems. Compaction by heavy machinery produces various impacts on the air, water, soil, earth surface, flora and fauna, and human beings (Enger and Smith, 2002). As regards the soils, the alterations of nutrient dynamics, especially $\mathrm{N}$ and $\mathrm{P}$ availability, increased soil acidity and introduction of toxic heavy metals can be localized or extend to nearby ecosystems through the air and local hydrology.

Heavy metals are naturally present in agricultural soils at low concentrations as the products of biological and 
geochemical cycles but increase to high levels through anthropogenic activities (Uwah et al., 2009). The persistent nature and cumulative behaviour through which they attain toxic levels with hazardous effects on plants and animals and so pose human health problems (Das et al., 1997; Islam et al., 2006) have increased research interest on identifying the sources of contamination. Rock and rock mineral exploitation activities are sources of additional heavy metals in soils. Blasting and crushing of rocks and use of explosives and heat to produce granite chips release particulate matter and dust of different metallic constituents from the machineries and blasting processes. Heavy metals are non-biodegradable, difficult to remove and on reaching the soil would accumulate through bonding to clay and organic colloids (Piccolo and Mbagwu, 1997). Plants growing in such contaminated soils can also bio-accumulate the metals at concentrations high enough to cause clinical problems such that understanding the presence in the soil-plant system is an important issue in current research on heavy metal risk assessment.

Investigations continue on effective, low-cost and environment-friendly methods which immobilize heavy metals in the ecosystem and render them less bioavailable. Plants contain heavy metals in relation to concentration and extent of availability in the soil, populations of particular plant species and the plant parts and so vital to phytoremediation- a method of decontamination in which plants accumulate the metals (phytoextraction) or restrict their dissemination from the sources of pollution (phytostabilization) (Kumar et al., 1995). Based on heavy metal uptake, Whiting (2000) identified four chemotaxonomic groups of plants for phytoextraction: excluders transfer negligible amounts of metals; shoot content of indicators is a good measure of soil pollution while accumulators and hyper-accumulators have large quantities concentrated in the shoots in relation to environmental factors which make the elements present in available forms. Many studies have shown greater capacity of some plants that grow naturally on contaminated land for heavy metal accumulation compared to levels normally encountered in plants and uncontaminated soils (Boularbah et al., 2006; Escarre et al., 2000) which suggest that such plants can be used to decontaminate heavily polluted soils. Ogundiran and Osibanjo (2008) identified six plant species that classify as hyperaccumulators for $\mathrm{Pb}, \mathrm{Ni}$ and $\mathrm{Zn}$ and three others as excluders in the vicinity of a battery waste dumpsite in Nigeria.

This study determined the heavy metal content in soils and plants in the immediate environment of a granite quarrying and stone crushing facility with which to assess the pollution threats and provide the information needed in developing appropriate land use strategies for the site.

\section{Materials and Methods}

The study site, located at Ikole-Ekiti ( $7^{\circ}{ }^{\prime} 45^{\prime} 44^{\prime \prime} \mathrm{N}, 5^{\circ} 30^{\prime}$ 40 'E) in Ekiti State, Nigeria is an old quarry opened in 1976 for the supply of rock aggregates needed for road construction. The operational area for blasting, grinding and loading of granite is about five hectares. Major quarrying activities ceased when the road contracts were concluded but the quarry was re-opened in 1996 and operated until 2003.

Surface $(0-15 \mathrm{~cm})$ and subsoil $(15-30 \mathrm{~cm})$ samples were taken at the quarry site $(0 \mathrm{~m}), 10,30,60,120$ and $200 \mathrm{~m}$ along the slope in the southern direction because of possible contamination from dust, emissions and runoff. A control (background) sample was taken at the Research Farm of Ekiti State Agricultural Development Programme, Ikole-Ekiti. The most abundant plant species at each sampling point were uprooted and taken to the Department of Plant Science, Ekiti State University for proper identification. The plants were rinsed in distilled water, separated into leaves, stems and roots and oven-dried at $80^{\circ} \mathrm{C}$ for 48 hours. The dried samples were milled to fine powder $(<1 \mathrm{~mm})$ in an agate mortar with pestle. Soil samples were air-dried and sieved $(<2 \mathrm{~mm})$ and analyzed for particle size distribution; $\mathrm{pH}$ in $1: 2(\mathrm{w} / \mathrm{v})$ soilwater suspension, organic carbon, exchangeable cations and exchangeable acidity using standard laboratory methods described in IITA (1979). Two (2) g of soil samples were digested with $10 \mathrm{ml} 30 \% \mathrm{HCl}$ and $3.5 \mathrm{ml} 65 \% \mathrm{HNO}_{3}$ on a Tecator Model 20 Digestor system at $150^{\circ} \mathrm{C}$ for 1 hour 30 minutes before heating at $230^{\circ} \mathrm{C}$ for another 30 minutes. The digestion tubes were removed and allowed to cool before washing the contents into $50 \mathrm{ml}$ volumetric flasks. The digestion of $0.5 \mathrm{~g}$ plant samples was with $5 \mathrm{ml}$ of the acid mixture on a Tecator Model 40 system using the same procedure. The heavy metals in the digests were determined with Atomic Absorption Spectrophotometer (Buck Scientific 205 Model with direct air-acetylene flame).

Simple correlation coefficients were calculated for the relationships between soil properties and heavy metals in soils and plants; among the heavy metals in the soil and between the heavy metals in soils and plants. The extent of heavy metal pollution at the specified distances of the quarry operations site was compared to the background (control or baseline concentration) and indicators of heavy metal enrichment calculated.

(1) Enrichment Factor (EF) was calculated from the relationship previously used by Liu et al. (2005) as:

$$
\frac{C_{n}(\text { sample }) / C_{\text {ref }}(\text { sample })}{\left.\left.B_{n} \text { (background }\right) / B_{\text {ref }} \text { (background }\right)}
$$

where

$\mathrm{C}_{\mathrm{n}}$ (sample) $=$ concentration of metals in the sample,

$\mathrm{C}_{\mathrm{ref}}($ sample $)=$ concentration of the reference metal in the sample

$\mathrm{B}_{\mathrm{n}}$ (background) $=$ concentration of the metal in background environment

$\mathrm{B}_{\text {ref }}$ (background $)=$ reference metal's concentration in the background.

The reference metal in this study was $\mathrm{Fe}$ because its abundance implied natural occurrence in soils (Agunbiade and Fawale, 2009). The EF interpretation is as follows: $<2.0$ 
means deficiency of mineral enrichment; 2.0-5.0 means moderate enrichment and $>5.0$ high level of enrichment.

(2) Contamination Factor $(\mathrm{CF})=\frac{\mathrm{C}_{\mathrm{m}} \text { sample }}{\mathrm{C}_{\mathrm{m}} \text { background }}$ where

$\mathrm{C}_{\mathrm{m}}($ sample $)=$ mean of the concentrations of individual metals from all distances

$\mathrm{C}_{\mathrm{m}}$ (background) $=$ background or baseline concentration of individual metal

The interpretation is in four categories of intensities on a scale of $1-6$ as follows: $0=$ none, $1=$ none-medium, $2=$ moderate, $3=$ moderate-strong, $4=$ strong, 5= strong-very strong, $6=$ very strong (Esshaimi et al., 2012).

(3) Pollution Load Index $(\mathrm{PLI})=\left(\mathrm{C}_{\mathrm{F} 1} \times \mathrm{C}_{\mathrm{F} 2} \times \mathrm{C}_{\mathrm{F} 3^{-------}}\right.$ $\left.\mathrm{C}_{\mathrm{Fn}}\right)^{1 / \mathrm{n}}$

where

$\mathrm{n}=$ number of metals investigated

$\mathrm{C}_{\mathrm{F}}=$ Concentration factor

$=$ ratio of concentration of each metal in sample to the baseline soil

PLI value below or close to 1 means baseline heavy metal loads while $>1$ means heavy metal pollution or accumulation at the site

(4) Transfer factor (TF) of the heavy metal into plants was where determined using the expression $\mathrm{C}_{\mathrm{p}} / \mathrm{C}_{\mathrm{s}}$

$\mathrm{C}_{\mathrm{p}}=$ concentration of the metal in plant sample

$\mathrm{C}_{\mathrm{s}}=$ concentration of the metal in corresponding soil sample

TF $>1$ means high level of heavy metal contamination in the plant

(5) Shoot/root quotient was determined as the concentration of individual heavy metal in the shoot compared to the concentration in the root with the expression $\mathrm{C}_{\mathrm{sh}} / \mathrm{C}_{\mathrm{r}}$

(6) Extraction coefficient as the concentrations of the heavy metals in the shoot divided by that in the soil as in the expression $\mathrm{C}_{\mathrm{sh}} / \mathrm{C}_{\mathrm{s}}$

\section{Results}

The means and ranges of soil properties at specific distances from the granite quarry and control sample are shown in Table 1. The soils were slightly acid loamy sands to sands in the topsoil and sandy loam to sands in the subsoil. Organic matter was $0.71-2.93 \%$ and $0.55-1.76 \%$ in the topsoil and subsoil respectively. ECEC was 4.95-9.12 and 4.64-9.47 cmol. $\mathrm{kg}^{-1}$ for the $0-15 \mathrm{~cm}$ and $15-30 \mathrm{~cm}$ layers of soil.

Table 1. Means and ranges of some physical and chemical properties of soils in the vicinity of the granite quarry at Ikole-Ekiti

\begin{tabular}{|c|c|c|c|c|}
\hline & \multicolumn{2}{|c|}{ Topsoil $(0-15 \mathrm{~cm})$} & \multicolumn{2}{|c|}{ Subsoil $(15-30 \mathrm{~cm})$} \\
\hline & Mean & Range & Mean & Range \\
\hline Sand, $\%$ & 80.4 & $72.2-86.2$ & 74.2 & $62.2-84.2$ \\
\hline Silt, \% & 10.7 & $6.6-14.6$ & 13.4 & $8.6-22.6$ \\
\hline Clay, \% & 8.9 & $7.2-15.2$ & 12.2 & $7.2-19.2$ \\
\hline Soil Textural Class & LS & SL-S & LS & SL-S \\
\hline $\mathrm{pH}$ (Water) & 6.3 & $5.9-6.8$ & 6.2 & $5.6-6.7$ \\
\hline Organic Matter, \% & 2.01 & $0.71-2.93$ & 1.22 & $0.55-1.76$ \\
\hline ECEC, $\mathrm{cmol}^{\mathrm{kg}}{ }^{-1}$ & 6.69 & $4.95-9.12$ & 6.10 & 4.64-9.47 \\
\hline
\end{tabular}

Soil Textural Class: $\mathrm{S}=$ Sand; $\mathrm{LS}=$ Loamy sand; $\mathrm{SL}=$ Sandy loam

$\mathrm{ECEC}=$ Effective Cation Exchange Capacity = Exchangeable bases+ Exchangeable acidity

Table 2. Means and ranges of heavy metal content in soils near a granite quarry at Ikole-Ekiti

\begin{tabular}{|c|c|c|c|c|c|c|}
\hline \multirow{2}{*}{ Elements* } & \multicolumn{3}{|c|}{ Topsoil $(0-15 \mathrm{~cm})$} & \multicolumn{3}{|c|}{ Subsoil (15-30 cm) } \\
\hline & Mean & Range & Control & Mean & Range & Control \\
\hline $\mathrm{Cd}$ & ND & ND & ND & ND & ND & ND \\
\hline Co & 3.04 & $2.25-3.50$ & 3.50 & 3.54 & $2.75-5.00$ & 5.50 \\
\hline $\mathrm{Cr}$ & 17.71 & $11.50-24.25$ & 11.75 & 17.29 & $11.25-27.00$ & 19.00 \\
\hline $\mathrm{Cu}$ & 2.63 & $1.50-4.00$ & 3.50 & 3.04 & $1.50-4.25$ & 3.25 \\
\hline $\mathrm{Mn}$ & 136.75 & $85.75-155.50$ & 142.25 & 135.83 & $79.50-156.75$ & 148.00 \\
\hline $\mathrm{Ni}$ & 3.54 & $2.25-4.25$ & 4.75 & 3.67 & $2.50-5.75$ & 5.50 \\
\hline $\mathrm{Pb}$ & 11.92 & $7.75-16.75$ & 10.00 & 12.25 & $10.25-17.75$ & 13.50 \\
\hline $\mathrm{Zn}$ & 7.01 & $3.50-14.55$ & 8.00 & 7.00 & $4.00-12.50$ & 9.50 \\
\hline
\end{tabular}

$\mathrm{ND}=$ below detectable level

*Heavy metals in mg.kg-1

$* * \mathrm{Fe}$ in $\%$

Table 2 shows the means and ranges of heavy metals in the $0-15 \mathrm{~cm}$ and $15-30 \mathrm{~cm}$ layers of soils at specific distances from the granite quarry site and the control sample. Fe was the most abundant and with the order heavy metals being: $\mathrm{Fe}>\mathrm{Mn}>\mathrm{Cr}>\mathrm{Pb}>\mathrm{Ni}>\mathrm{Cu}>\mathrm{Co} . \mathrm{Cd}$ was below detectable level in the soils. The mean values with soil depth showed $42.5 \%$ increase in $\mathrm{Fe}$, slight increases in $\mathrm{Co}, \mathrm{Cu}, \mathrm{Pb}$ and $\mathrm{Ni}$ and slight reduction in $\mathrm{Mn}, \mathrm{Zn}$ and $\mathrm{Cr}$.
Table 3 shows the correlation coefficients of the relationships between soil properties and heavy metal contents. The only significant correlations were between clay and $\mathrm{Zn}\left(\mathrm{r}=0.77^{* *}\right), \mathrm{pH}$ and $\mathrm{Cu}(\mathrm{r}=-0.69)$, ECEC and $\mathrm{Zn}$ $(\mathrm{r}=0.56 *)$ and $\mathrm{Cr}(\mathrm{r}=-0.70 * *)$ while organic matter showed poor correlations with all the heavy metals. The relationships between the heavy metals in the soils (Table 4) show that the following pairs had significant correlations: $\mathrm{Cu} / \mathrm{Fe}, \mathrm{Cu} / \mathrm{Co}$; 
$\mathrm{Mn} / \mathrm{Cr} ; \mathrm{Pb} / \mathrm{Fe}, \mathrm{Pb} / \mathrm{Co} ; \mathrm{Fe} / \mathrm{Co}, \mathrm{Fe} / \mathrm{Ni}$ and $\mathrm{Co} / \mathrm{Ni}$

Table 3. Relationships between some soil properties and heavy metal contents in soils near the granite quarry at Ikole-Ekiti

\begin{tabular}{lllll}
\hline Heavy & \multicolumn{2}{l}{ Soil properties } & & \\
\cline { 2 - 5 } Metals & pH & Clay & Organic carbon & ECEC \\
\hline $\mathrm{Co}$ & -0.19 & 0.31 & -0.20 & 0.29 \\
$\mathrm{Cr}$ & 0.29 & -0.20 & -0.24 & $-0.70^{* *}$ \\
$\mathrm{Cu}$ & $-0.69^{* *}$ & 0.04 & 0.15 & 0.49 \\
$\mathrm{Fe}$ & -0.11 & 0.11 & -0.09 & 0.27 \\
$\mathrm{Mn}$ & -0.02 & 0.33 & -0.04 & 0.28 \\
$\mathrm{Ni}$ & -0.19 & 0.51 & 0.21 & 0.19 \\
$\mathrm{~Pb}$ & -0.09 & 0.04 & -0.08 & 0.20 \\
$\mathrm{Zn}$ & 0.14 & $0.77^{* *}$ & 0.24 & $0.56^{*}$ \\
\hline
\end{tabular}

Table 4. Correlation matrix of the relationships between heavy metal contents of soils in the vicinity of a granite quarry at Ikole-Ekiti

\begin{tabular}{|c|c|c|c|c|c|c|c|c|}
\hline & Co & $\mathrm{Cr}$ & $\mathrm{Cu}$ & $\mathrm{Fe}$ & Mn & $\mathbf{N i}$ & $\mathbf{P b}$ & $\mathbf{Z n}$ \\
\hline Co & - & -0.16 & $0.53 *$ & $0.82 * *$ & 0.01 & $0.58^{*}$ & $0.55^{*}$ & 0.19 \\
\hline $\mathrm{Cr}$ & & - & -0.35 & 0.09 & $-0.67 * *$ & 0.14 & 0.13 & -0.51 \\
\hline $\mathrm{Cu}$ & & & - & $0.56^{*}$ & -0.13 & $0.65^{*}$ & 0.28 & 0.11 \\
\hline $\mathrm{Fe}$ & & & & - & -0.46 & $0.69 * *$ & $0.78 * *$ & -0.06 \\
\hline $\mathrm{Mn}$ & & & & & - & -0.48 & -0.49 & 0.37 \\
\hline $\mathrm{Ni}$ & & & & & & - & -0.27 & 0.14 \\
\hline $\mathrm{Pb}$ & & & & & & & - & -0.15 \\
\hline $\mathrm{Zn}$ & & & & & & & & - \\
\hline
\end{tabular}

Table 5. Enrichment Factors of heavy metals in the vicinity of a granite quarry at Ikole-Ekiti

\begin{tabular}{|c|c|c|c|c|c|c|c|c|}
\hline Distance & Co & $\mathrm{Cr}$ & $\mathbf{C u}$ & $\mathrm{Fe}$ & Mn & $\mathbf{N i}$ & $\mathbf{P b}$ & $\mathbf{Z n}$ \\
\hline Topsoil & \multicolumn{8}{|c|}{$0-15 \mathrm{~cm}$} \\
\hline $0 \mathrm{~m}$ & 0.70 & 1.55 & 0.97 & 1.64 & 0.62 & 0.87 & 1.49 & 0.59 \\
\hline $10 \mathrm{~m}$ & 2.24 & 3.28 & 1.23 & 0.34 & 3.00 & 1.26 & 2.99 & 1.98 \\
\hline $30 \mathrm{~m}$ & 1.61 & 2.42 & 1.59 & 0.46 & 2.18 & 1.73 & 2.17 & 4.04 \\
\hline $60 \mathrm{~m}$ & 1.83 & 2.41 & 3.13 & 0.34 & 2.93 & 2.01 & 1.80 & 2.23 \\
\hline $120 \mathrm{~m}$ & 1.57 & 4.96 & 1.35 & 0.33 & 3.02 & 1.84 & 2.73 & 1.38 \\
\hline $200 \mathrm{~m}$ & 0.85 & 0.88 & 1.01 & 0.85 & 1.19 & 0.92 & 1.30 & 1.11 \\
\hline Subsoil & \multicolumn{8}{|c|}{$15-30 \mathrm{~cm}$} \\
\hline $0 \mathrm{~m}$ & 0.72 & 1.42 & 0.81 & 2.28 & 0.44 & 0.91 & 0.91 & 0.41 \\
\hline $10 \mathrm{~m}$ & 1.33 & 2.49 & 1.03 & 0.41 & 2.44 & 1.17 & 2.13 & 1.79 \\
\hline $30 \mathrm{~m}$ & 1.20 & 1.70 & 1.28 & 0.57 & 1.77 & 1.14 & 1.56 & 2.81 \\
\hline $60 \mathrm{~m}$ & 1.69 & 1.70 & 2.49 & 0.43 & 2.35 & 1.70 & 1.98 & 2.31 \\
\hline $120 \mathrm{~m}$ & 1.18 & 2.65 & 1.27 & 0.57 & 1.76 & 1.04 & 1.65 & 0.89 \\
\hline $200 \mathrm{~m}$ & 0.77 & 0.51 & 0.84 & 1.48 & 0.68 & 0.51 & 2.04 & 0.61 \\
\hline
\end{tabular}

Table 5 shows the Enrichment Factors of heavy metals in the soils and based on the interpretation criteria, the metals showed moderate enrichment at some distances but more in the surface layer $(0-15 \mathrm{~cm})$ than in the subsoil $(15-30 \mathrm{~cm})$. The pattern in the surface soil layer is as follows: $\mathrm{Cu}$ at $60 \mathrm{~m}$; $\mathrm{Mn}, \mathrm{Pb}$ and $\mathrm{Cr}$ at 10-120 $\mathrm{m}$ range; $\mathrm{Zn}$ at 30 and $60 \mathrm{~m}$; $\mathrm{Co}$ and $\mathrm{Ni}$ at 10 and $60 \mathrm{~m}$, respectively while values in the other distances indicate deficiency. Most of the metals were deficient values in the subsoil while the enrichment was moderate for $\mathrm{Fe}$ at $0 \mathrm{~m}, \mathrm{Cu}$ at $60 \mathrm{~m}, \mathrm{Mn}$ at 10 and $60 \mathrm{~m}$ for $\mathrm{Mn}, \mathrm{Zn}$ at 30 and $60 \mathrm{~m}, \mathrm{~Pb}$ at $10 \mathrm{~m}$ and $\mathrm{Cr}$ at 10 and $120 \mathrm{~m}$. The Contamination Factors shown in Table 6 were low at the various points from the quarry operational area with the values at $<1.0$ in all surface locations for $\mathrm{Co}, \mathrm{Cu}$ and $\mathrm{Zn}$ but moderate $(\mathrm{CF}=1.0-3.0)$ at 10,60 and $30 \mathrm{~m}$, respectively. The values of $\mathrm{CF}$ for $\mathrm{Cr}$ at $0-30$ and $120 \mathrm{~m}$; $\mathrm{Mn}$ at 10 and $60 \mathrm{~m}$; and $\mathrm{Pb}$ at 0,10 and $200 \mathrm{~m}$ also indicated moderate contamination. The contamination of $\mathrm{Cu}, \mathrm{Cr}, \mathrm{Cu}, \mathrm{Fe} \mathrm{Ni}$ and $\mathrm{Pb}$ at $0 \mathrm{~m}$ and $\mathrm{Co}, \mathrm{Cu}, \mathrm{Fe}$ and $\mathrm{Pb}$ at $200 \mathrm{~m}$ in the subsoil was moderate. The Pollution Load Index (PLI) was $<1.0$ at all points in the surface layer with highest values at 0 and $30 \mathrm{~m}$ (PLI=0.90) while only $200 \mathrm{~m}$ had PLI $>1.0$.

Table 6. Contamination Factors of heavy metals from granite quarrying operations at Ikole-Ekiti

\begin{tabular}{llllllllll}
\hline $\begin{array}{l}\text { Distance, } \\
\mathbf{m}\end{array}$ & Co & Cr & Cu & Fe & Mn & Ni & Pb & Zn & PLI \\
\hline Topsoil & $0-15 \mathrm{~cm}$ & & & & & & & \\
$0 \mathrm{~m}$ & 0.89 & 1.48 & 0.96 & 0.96 & 0.59 & 0.83 & 1.43 & 0.51 & 0.901 \\
$10 \mathrm{~m}$ & 1.04 & 1.14 & 0.44 & 0.35 & 1.03 & 0.44 & 1.04 & 0.63 & 0.695 \\
$30 \mathrm{~m}$ & 0.96 & 1.09 & 0.74 & 0.45 & 0.97 & 0.78 & 0.98 & 1.66 & 0.900 \\
$60 \mathrm{~m}$ & 0.89 & 0.88 & 1.18 & 0.37 & 1.06 & 0.73 & 0.66 & 0.74 & 0.774 \\
$120 \mathrm{~m}$ & 0.67 & 1.58 & 0.44 & 0.32 & 0.95 & 0.59 & 0.87 & 0.40 & 0.643 \\
$200 \mathrm{~m}$ & 0.96 & 0.75 & 0.89 & 0.85 & 0.99 & 0.78 & 1.11 & 0.86 & 0.892 \\
Mean & 0.90 & 1.15 & 0.78 & 0.55 & 0.92 & 0.69 & 1.02 & 0.80 & \\
Subsoil & $15-30 \mathrm{~cm}$ & & & & & & & \\
$0 \mathrm{~m}$ & 1.18 & 1.76 & 1.04 & 1.24 & 0.54 & 1.12 & 1.13 & 0.46 & 0.979 \\
$10 \mathrm{~m}$ & 0.81 & 1.04 & 0.44 & 0.42 & 1.01 & 0.49 & 0.89 & 0.69 & 0.683 \\
$30 \mathrm{~m}$ & 0.89 & 0.94 & 0.74 & 0.56 & 0.98 & 0.63 & 0.87 & 1.43 & 0.848 \\
$60 \mathrm{~m}$ & 1.04 & 0.78 & 1.18 & 0.46 & 1.07 & 0.78 & 0.92 & 0.97 & 0.870 \\
$120 \mathrm{~m}$ & 0.89 & 1.50 & 0.74 & 0.57 & 0.98 & 0.59 & 0.94 & 0.46 & 0.783 \\
$200 \mathrm{~m}$ & 1.48 & 0.73 & 1.26 & 1.45 & 0.98 & 0.73 & 1.51 & 0.80 & 1.069 \\
Mean & 1.05 & 1.12 & 0.90 & 0.78 & 0.93 & 0.72 & 1.04 & 0.80 & \\
\hline
\end{tabular}

PLI= Pollution Load Index

Table 7. Total heavy metal contents of plant species near a granite quarry at Ikole-Ekiti, Nigeria

\begin{tabular}{|c|c|c|c|c|c|c|c|c|}
\hline Sample & Plant species & Co & $\mathrm{Cu}$ & $\mathbf{F e}$ & Mn & $\mathbf{N i}$ & $\mathbf{P b}$ & Zn \\
\hline Control & $\begin{array}{l}\text { Tithonia } \\
\text { diversifolia }\end{array}$ & 25.0 & 18.0 & 250.0 & 98.0 & 2.0 & 14.0 & 6.0 \\
\hline $0 \mathrm{~m}$ & Sida scabrida & 15.0 & 24.0 & 327.0 & 258.0 & 11.0 & 20.0 & 5.5 \\
\hline $10 \mathrm{~m}$ & $\begin{array}{l}\text { Aspilia } \\
\text { africana }\end{array}$ & 38.0 & 73.0 & 448.0 & 240.0 & 7.0 & 35.0 & 10.0 \\
\hline $30 \mathrm{~m}$ & Sida scabrida & 22.0 & 0.0 & 1149.0 & 131.0 & 10.0 & 19.0 & 12.0 \\
\hline $60 \mathrm{~m}$ & $\begin{array}{l}\text { Synedrella } \\
\text { nodiflora }\end{array}$ & 27.0 & 5.0 & 205.0 & 142.0 & 13.0 & 14.0 & 9.5 \\
\hline $120 \mathrm{~m}$ & $\begin{array}{l}\text { Chromolaena } \\
\text { odorata }\end{array}$ & 19.0 & 65.0 & 9432.0 & 209.0 & 13.0 & 25.0 & 8.0 \\
\hline $200 \mathrm{~m}$ & $\begin{array}{l}\text { Talinum } \\
\text { triangulare }\end{array}$ & 10.5 & 6.0 & 488.0 & 305.0 & 9.0 & 11.0 & 10.5 \\
\hline
\end{tabular}

Table 7 shows the total heavy metal content in some most abundant plants within $200 \mathrm{~m}$ of the granite quarry site. The heavy metals varied between $0 \mathrm{mg} \cdot \mathrm{kg}^{-1} \mathrm{Cu}$ in Sida scrabida at $30 \mathrm{~m}$ to $9,432 \mathrm{mg} \cdot \mathrm{kg}^{-1} \mathrm{Fe}$ in Chromolaena odorata at 120 $\mathrm{m}$. The most abundant heavy metals in the plant species were $\mathrm{Fe}$ and $\mathrm{Mn}$. The highest heavy metal contents were obtained as follows: $\mathrm{Cu}$ in Chromolaena odorata at $120 \mathrm{~m}$ and Aspilia africana at $10 \mathrm{~m} ; \mathrm{Fe}$ in Chromolaena odorata at 120 and Sida scrabida at $30 \mathrm{~m}$; Mn in Sida scrabida at $0 \mathrm{~m}$ and Talinum triangulare at $200 \mathrm{~m}$; $\mathrm{Co}$, $\mathrm{Co}$ and $\mathrm{Pb}$ in Aspilia africana at $10 \mathrm{~m} ; \mathrm{Zn}$ content in Sida scrabida at 30 and 200 $\mathrm{m}$; and Ni in Synedrella nodiflora and Chromolaena odorata at 60 and $120 \mathrm{~m}$ respectively. $\mathrm{Cd}$ and $\mathrm{Cr}$ were below detectable levels in all the plants. 
Table 8. Transfer Factor, Shoot: Root Quotient and Extraction Ratio of heavy metals in the vicinity of a granite quarry at Ikole-Ekiti

\begin{tabular}{llllllll}
\hline $\begin{array}{l}\text { Distance, } \\
\mathbf{m}\end{array}$ & Co & Cu & Fe & Mn & Ni & Pb & Zn \\
\hline a) TF & & & & & & & \\
Control & 7.14 & 5.54 & 0.03 & 0.68 & 0.42 & 1.40 & 0.75 \\
$0 \mathrm{~m}$ & 5.00 & 7.39 & 0.03 & 3.01 & 2.59 & 1.19 & 1.22 \\
$10 \mathrm{~m}$ & 10.86 & 48.67 & 0.12 & 1.59 & 3.11 & 2.86 & 1.87 \\
$30 \mathrm{~m}$ & 6.77 & 0.00 & 0.23 & 0.92 & 2.50 & 1.65 & 0.83 \\
$60 \mathrm{~m}$ & 9.00 & 1.25 & 0.05 & 0.91 & 3.47 & 1.81 & 1.46 \\
$120 \mathrm{~m}$ & 8.44 & 43.33 & 2.64 & 1.50 & 4.33 & 2.44 & 2.29 \\
$200 \mathrm{~m}$ & 3.23 & 2.00 & 0.05 & 2.09 & 2.25 & 0.85 & 1.40 \\
b) SRQ & & & & & & & \\
Control & 1.78 & 5.00 & 2.09 & 3.08 & 20.00 & 6.00 & 2.00 \\
$0 \mathrm{~m}$ & 4.00 & 1.00 & 3270 & 5.62 & 1.75 & 1.86 & 2.67 \\
$10 \mathrm{~m}$ & 2.17 & 1.61 & 1.01 & 3.00 & 2.50 & 2.50 & 1.00 \\
$30 \mathrm{~m}$ & 2.14 & 1.00 & 0.94 & 2.85 & 2.33 & 2.17 & 0.92 \\
$60 \mathrm{~m}$ & 2.38 & 1.50 & 0.69 & 3.58 & 1.60 & 2.50 & 1.71 \\
$120 \mathrm{~m}$ & 1.71 & 3.64 & 8.63 & 3.86 & 2.25 & 1.78 & 0.78 \\
$200 \mathrm{~m}$ & 1.63 & 5.00 & 4.61 & 3.36 & 0.80 & 1.75 & 1.63 \\
c) ER & & & & & & & \\
Control & 4.57 & 4.29 & 0.02 & 0.51 & 0.42 & 1.20 & 0.50 \\
$0 \mathrm{~m}$ & 4.00 & 3.69 & 0.03 & 2.55 & 2.59 & 0.78 & 0.89 \\
$10 \mathrm{~m}$ & 7.43 & 30.00 & 0.06 & 1.19 & 3.11 & 2.04 & 0.91 \\
$30 \mathrm{~m}$ & 4.62 & 0.00 & 0.11 & 0.68 & 2.50 & 1.13 & 0.41 \\
$60 \mathrm{~m}$ & 6.33 & 0.75 & 0.02 & 0.71 & 3.47 & 1.54 & 0.92 \\
$120 \mathrm{~m}$ & 5.33 & 34.00 & 2.37 & 1.19 & 4.33 & 1.56 & 1.00 \\
$200 \mathrm{~m}$ & 1.96 & 1.67 & 0.04 & 1.61 & 2.25 & 0.59 & 0.93 \\
\hline
\end{tabular}

$\mathrm{TF}=$ Transfer Factor; $\mathrm{SRQ}=$ Shoot: Root Quotient; ER= Extraction Ratio

The values of Transfer Factor (TF), Shoot: Root Quotient (SRQ) and Extraction Coefficient (EC) calculated for the heavy metals are shown in Table 8 . The TF values exceeded 1.00 for most of the heavy metals especially at 0 and $10 \mathrm{~m}$ where contamination was indicated in the plants compared to the control. There was no Fe contamination except at $120 \mathrm{~m}$ with TF of 2.64 while the value of 0.00 for $\mathrm{Cu}$ at $30 \mathrm{~m}$ was due to its undetectable level in the plant. The SRQ values exceeded 1.0 for most heavy metals except Fe at 30 and $60 \mathrm{~m}$ $\mathrm{Zn}$ at $30 \mathrm{~m}$ and $\mathrm{Ni}$ at $200 \mathrm{~m}$. No value could be given for $\mathrm{Fe}$ which was below detectable level in the plant roots at $0 \mathrm{~m}$. The EC values were highest at 30.00 and 34.00 for $\mathrm{Cu}$ at 10 and $120 \mathrm{~m}$ but lowest for $\mathrm{Fe}$ and $\mathrm{Zn}(<1.0)$ except at $120 \mathrm{~m}$ with a value of 2.37 and 1.00 respectively. The values of $\mathrm{Cu}$, $\mathrm{Mn}, \mathrm{Ni}, \mathrm{Pb}$ and $\mathrm{Zn}$ indicated increased extraction at $0-10 \mathrm{~m}$ compared to the control.

\section{Discussion}

The soil properties are typical of soils formed on parent materials derived from basement complex rocks, especially in soil reaction, coarse-textured surface layer (loamy sand to sand with mean $8.9 \%$ clay) overlying fine-textured subsoil (sandy loam to sand with mean $12.2 \%$ clay) and decreasing organic matter with soil depth. The higher clay content in the subsoil agrees with diagnostic criterion for the argillic or kandic B horizons in Alfisols and Ultisols formed under warm, humid tropical conditions (Ogunkunle, 2009). The amount of heavy metals with depth was not consistent as shown by slightly higher mean values of $\mathrm{Cu}, \mathrm{Pb}, \mathrm{Ni}$ and $\mathrm{Co}$ in the subsoil unlike the wider difference in $\mathrm{Fe}$ between the surface (6141.25 mg. $\mathrm{kg}^{-1}$ ) and subsoil (8753.67 mg. $\mathrm{kg}^{-1}$ ) which was probably due to formation of large amounts of $\mathrm{Fe}$ oxides and hydroxides as weathering products (Brady and Weil, 2002). Ayodele and Balogun (2013) had reported the trend in distribution of the heavy metals in this granite quarry as $\mathrm{Fe}, \mathrm{Pb}, \mathrm{Cu}, \mathrm{Cr}$ and $\mathrm{Ni}$ being highest at $0 \mathrm{~m}$ and decreased with distance. Bada and Fagbayigbo (2009) had observed similar decrease of heavy metal concentrations with distance from a stone quarry which confirms this as the potential source of soil contamination. This might be due to heavy metals emitted in particulate matter and which settled under gravity near the point source (Haygarth and Jones, 1992). Pb, $\mathrm{Cr}$ and $\mathrm{Mn}$ decreased with depth probably because of the higher organic matter content of the topsoil which probably ensures fixation of the heavy metals in soils (Nyangadabo and Hamya, 1986). Usero et al. (2000) had observed that the decrease in heavy metal content with soil depth suggested anthropogenic sources of contamination.

The relationships with soil properties show that clay and organic matter had little influence on the contents of heavy metals in the soils. Clay has high correlations with $\mathrm{Zn}$ and $\mathrm{Ni}$ but only the former is significant while the low correlations with $\mathrm{Fe}$ and $\mathrm{Mn}$ are unexpected. The decrease of Mn content with depth can explain the low correlation but not of Fe which is usually associated with the clay component and it also increased with depth. The correlations of heavy metal cations with $\mathrm{pH}$ were negative and positive with the anion heavy metal- $\mathrm{Cr}$, however only the correlation with $\mathrm{Cu}$ was significant. The significant positive correlations of $\mathrm{Fe}$ with $\mathrm{Cu}, \mathrm{Pb}, \mathrm{Co}$ and $\mathrm{Ni}$; and $\mathrm{Co}$ with $\mathrm{Cu}, \mathrm{Pb}$ and $\mathrm{Ni}$ suggest similar sources of enrichment whereas the significant correlations of $\mathrm{Cr}$ with $\mathrm{Mn}$ and $\mathrm{Zn}$ were negative.

The pollution assessment indices show that contamination of the various points with heavy metals as indicated by most $\mathrm{EF}$ and $\mathrm{CF}$ values within the class of moderate enrichment and none-medium contamination respectively. Thus, the use of PLI which provides a simple comparative means of assessing the level of heavy metal pollution in a site indicates that the level of pollution is low $(\mathrm{PLI}<1.0)$. The quarry has been closed for a decade and only subsistence level collection and cracking of stones by women and children take place. Thus, the pollution effects of blasting and mechanized operations in stone crushing and transportation found where granite quarrying activities persist (Bada and Fagbayigbo, 2009; Oguntoke et al., 2009) are no longer obvious. Thus, even if the site had been polluted with heavy metals in the past, the time interval since active quarrying operations stopped and taking of samples was probably long enough to have worn off such pollution through surface runoff by erosive agents.

Different plant species were found at the sampling points from the quarry and so the correlation analysis between soil and plant heavy metal contents was not carried out. However, based on total content irrespective of plant species, Fe content was highest and followed by $\mathrm{Mn}$ while $\mathrm{Zn}$ and $\mathrm{Ni}$ were the least. With regards to the baseline (control) values, there were elevated levels of $\mathrm{Cu}, \mathrm{Mn}, \mathrm{Fe}, \mathrm{Pb}$ and $\mathrm{Ni}$ at 0 and $10 \mathrm{~m}$. Bada 
and Fagbayigbo (2009) had observed highest total $\mathrm{Pb}$ and $\mathrm{Ni}$ concentration in vegetation within quadrants taken at $1 \mathrm{~m}$ radius from a granite quarry and the values decreased with distance up to $500 \mathrm{~m}$ radius. The $\mathrm{TF}$ which quantifies the relative efficiencies of the plant species in heavy metal bioavailability and so the differences in their bioaccumulation was based on the assumption of heavy metal uptake by the roots only and not through possible foliar absorption from atmospheric metal deposits in the particulate matter (Awode et al., 2008). The control had lower TF values for the heavy metals than at $0 \mathrm{~m}$, except $\mathrm{Pb}$ and $\mathrm{Co}$, but which point to elevated concentrations in the plants above the levels in the soils. Thus, the highest transfers were: $\mathrm{Cu}, \mathrm{Pb}$ and $\mathrm{Co}$ in Aspilia africana at $10 \mathrm{~m}, \mathrm{Mn}$ in Sida scrabida at $0 \mathrm{~m}$ and $\mathrm{Fe}$, $\mathrm{Zn}$ and Ni in Chromolaena odorata at $120 \mathrm{~m}$. The SRQ and EC demonstrate the abilities of plant roots, which are in direct contact with the soil solution, to extract and accumulate heavy metals in the above-ground parts (stems, leaves and flowers/fruits) (Hogan, 2010) and with values greater than 1.00 showing more proportional concentration of the heavy metals in the shoot. Alloway and Ayres (1997) had shown that metal uptake is affected by plant species and age, nature of soil and climate. The climatic condition is the same within the sampling location but the variations in heavy metal concentrations in the plants and the indices of bioavailability would be better ascribed to differences in plant species and age, soil properties and type of metal being considered.

The elevated heavy metal levels in soil and plants, especially within the $10 \mathrm{~m}$ distance, can pose potential health hazards to animals consuming the above-ground parts of plants Most of the plants found in the site are weeds not presently used as ruminant feeds but can be important components of the food web. Talinum triangulare found at $200 \mathrm{~m}$ is in widespread use as a leaf vegetable and should not pose health problems given $\mathrm{Cu}$ and $\mathrm{Zn}$ contents below the published threshold in plant tissue dry matter (Kabata-Pendias and Pendias, 2001) and Mn less than critical level regarded as excessive but within the range set for Fe (EC-UN/ECE, 1995).

The enrichment of this leaf vegetable with these essential micronutrients has nutritional advantage whereas $\mathrm{Pb}, \mathrm{Ni}$ and Co would be of serious concern because of the negative effects they have on the biotic environment and which emphasize adequate control of their sources. The concentrations are relevant to phytoremediation of heavy metal-polluted soils in relation to whether the plants are excluders, indicators, accumulators or hyperaccumulators (Nathalie and Sylvie, 2002). All the plant species are excluders of Cr, Sida scabrida, Synedrella nodiflora and Talinum triangulare are excluders of $\mathrm{Cu}$ while Talinum triangulare, Sida scabrida and Chromolaena odorata are possible excluders of Co. Chromolaena odorata is the highest accumulator of $\mathrm{Fe}$ followed by Sida scabrida, Talinum triangulare and Aspillia a338fricana while Talinum triangulare, Sida scabrida and Aspilia 338africana can be used to extract Mn from polluted soils. Chromolaena odorata meets the criteria set for hyperaccumulators- shoot concentration of 10-500 times more than in normal plants
(Rotkittikhun et al., 2006) -for Fe but the plants qualify based on SRQ and EC>1.00 for all or some of the heavy metals. All the plant species are excluders of $\mathrm{Cr}$, Sida scabrida, Synedrella nodiflora and Talinum triangulare are excluders of $\mathrm{Cu}$ while Talinum triangulare, Sida scabrida and Chromolaena odorata are possible excluders of Co. The extent of tolerance to high $\mathrm{Fe}$ by Chromolaena odorata despite the low content in the soil is worthy of note such that after the accumulating ability has been established, the plant can be recommended for decontamination of Fe-polluted soils.

\section{References}

[1] Agunbiade, F.O. and Fawale, A.T. 2009. Use of Siam weed biomarker in assessing heavy metal contamination in traffic and solid waste polluted areas. Int. J. Environ. Sci. Tech. 6: 267-276

[2] Alloway, B.J. and Ayres, D.C. 1993. Chemical Principles of Environmental Pollution. Blackie Academic and Professional, Glasgow

[3] Awode, U.A., Uzairu, A., Balarabe, M.L., Okunola, O.J. and Adewusi, S.G. 2008. Levels of some trace metals in the Fadama soils and pepper (Capsicum annuum) along the bankof River Challawa, Nigeria. Asian J. Sci. Res.

[4] Ayodele, O.J. and Balogun, T. 2013. Heavy metal content of soils and vegetation in the vicinity of a granite rock quarry at Ikole-Ekiti, Nigeria. In Press

[5] Bada, B.S. and Fagbayigbo, B.A. 2009. Heavy metal levels in soil and vegetation in the vicinity of a quarry. In: Fasina, A.S. et al. (eds). Management of Nigerian Soil Resources for Enhanced Agricultural Productivity, Proceedings of $33^{\text {rd }}$ Annual Conference of Soil Science Society of Nigeria, University of Ado-Ekiti, Nigeria; 9-13 March 2009: 280-284.

[6] Boularbah, A., Schwartz, C., Bitton, G., Aboudrar, W., Ouhammou, A. and Morel, J.L. 2006. Heavy metal contamination from mining sites in South Morocco: 2. Assessment of metal contamination and toxicity in plants. Chemosphere 63: 811-817

[7] Brady, N.C and Weil, R.R. 2002. The Nature and Properties of Soils. $12^{\text {th }}$ Edition. Prentice Hall, Saddle River, New York. 881pp.

[8] Das, P., Samantarary, S. and Rout, G.R. 1997. Studies on cadmium toxicity in plants: a review. Environ. Pollution 98: $28-36$

[9] EC-UN/ECE (Economic Commission- United Nations). 1995. Foliar Expert Panel. Symposium Paper ICP-Forest, Wien,6-8 ${ }^{\text {th }}$ Nov. 1995

[10] Enger, E.D. and Smith, B.F. 2002. Environmental Science: A study of Interrelationships ( $8^{\text {th }}$ Edition). McGraw-Hill Higher Education, New York: 372-377

[11] Escarre, J., Lefebvre, C., Gruber, W., Leblanc, M., Lepart, L., Riviere,Y. and Delay, B. 2000. Zinc and cadmium hyperaccumulation by Thiaspi caerulescens from metalliferous and nonmetalliferous sites in the Mediterranean area: implications for phytoremediation: New Phytol. 145: 429-437. 
[12] Esshaimi, M., Quazzani, N., Avila, M., Perez, G., Valiente, M. and Mandi, L. 2012. Heavy metal contamination of soils and water resources in Kettara abandoned mine. Amer. J. Environ. Sci. 8: 253-261

[13] Haygarth, P.M. and Jones, K.C. (1992). Atmospheric deposition of metal to agricultural surfaces. In: Adriano, D.C. (ed) Biogeochemistry of Trace Metals. CRC Press, Boca Raton: 249-276

[14] IITA (1979). Selected Methods of Soil and Plant Analysis. Manual Series No 1. International Institute of Tropical Agriculture, Ibadan, Nigeria. 70pp.

[15] Islam, E., Yang, X., He, Z. and Mahmood, Q. 2006. Assessing potential dietary toxicity of heavy metals in selected vegetables and food crops. J. Zhejiang University Sci. B 8: 113

[16] Kabata-Pendias, A. and Pendias, H. 2001. Trace Elements in Soils and Plants. $3^{\text {rd }}$ Edition. CRC Press, Boca Raton, Florida.

[17] Kumar, P.B.A.N., Dushenkov, V., Motto, H., Raskin, I. 1995. Phytoremediation: the use of plants to remove heavy metals from soils. Environ. Sci. Technol. 29: 1232-1238

[18] Liu, W., Zhao, J., Ouyang, Z., Soderlund, L., Liu, G. 2005. Impacts of sewage irrigation on heavy metal distribution and contamination in Beijing, China. Environ. Int. 31: 805-812

[19] Mallo, S.J. 2012. The Nigerian Mining Sector: an overview. Cont. J. Appl. Sci. 7: 34-45

[20] Nathalie, K. and Sylvie, D. 2002. Environmental risk of applying sewage to agricultural fields. J. Environ. Quality 31: $1522-1527$

[21] Nyangadabo, J.T. and Hamya, J.W. 1986. The depositions of lead, cadmium, zinc and copper from motor traffic on Bracharia enimi and soil along a major Bombo road in Kampala City. Int. J. Env. Studies 27: 115-119.

[22] Odeyemi, I.B. 2001. Minerals and Man: An Inseparable Duo. In: Saliu, N.B. (Compiler). Nigerian Universities Inaugural Lecture Series 2001. National Universities Commission, Abuja, Nigeria: 567-587.
[23] Ogundiran, M.B. and Osibanjo, O. 2008. Heavy metal concentrations in soils and accumulation in plants growing in a deserted slag dumpsite in Nigeria. African J. Biotech. 7: 3053-3060

[24] Ogunkunle, A.O. 2009. Management of Nigeria's soil resources for sustainable agricultural productivity and food security. In: Fasina, A.S. et al. (eds). Management of Nigeria's Soil Resources for Enhanced Agricultural Productivity. Proceedings of $33^{\text {rd }}$ Annual Conference of Soil Science Society of Nigeria, held at University of Ado-Ekiti, 9-13 ${ }^{\text {th }}$ March, 2009: 9-25.

[25] Oguntoke,O., Aboaba, A. and Gbadebo, T.A. 2009. Impact of granite quarrying on the health of workers and nearby residents in Abeokuta, Ogun State, Nigeria. Ethiopian Journal of Environ. Studies and Mgt. 2: 1-11

[26] Oyinloye, A.O. and Obasi, R. 2006. Geology, geochemistry and geotectonic setting of the Pan-African granites and charnockites around Ado-Ekiti, south-western Nigeria. Pakistan J. Sci. and Ind. Res. 49: 299-308.

[27] Piccolo, A. and Mbagwu, J.S.C. 1997. Exogenous humic substances as conditions for rehabilitation of degraded soils. Agro-Foods Industry Hi-Tech. March/April: 21-28.

[28] Rotkittikhun, R., Kruatrachue, M., Chaiyarat, R., Ngernsansaruay, C. Pokethitiyook, P., Paijitprapaporn, A and Baker, A.J.M. 2006. Uptake and accumulation of lead by plants from the Bo Ngam lead mine area in Thailand. Environ. Pollut. 144: 681-688

[29] Shitta, K.A. 2007. Lithostratigraphy of Nigeria: an overview. Proceedings of $32^{\text {nd }}$ Workshop on Geothermal Reservoir Engineering held at Stanford University, Stanford, California; 22-24 Jan. 2007: 18-23.

[30] Uwah, E.I., Ndahi, N.P., Abdurlahman, F.I. and Ogugbuaja, V.O. 2011. Heavy metal levels in spinach (Amaranthus caudatus) and lettuce (Lactuca sativa) grown in Maiduguri, Nigeria. J. Environ. Chem. and Ecotox. 3: 264-271

[31] Whiting, S.N (2000). Positive responses to $\mathrm{Zn}$ and $\mathrm{Cd}$ by roots of $\mathrm{Zn}$ and $\mathrm{Cd}$ hyperaccumulator Thlaspi caerulescens. New Phytol 145: 199-210. 